ORIGINAL ARTICLE

\title{
Diversity of yeasts during fermentation of cocoa from two sites in the Brazilian Amazon
}

\author{
Silvana de F. Oliveira de ALMEIDA ${ }^{1 *}$, Letícia R Carvalho SILVA ${ }^{1}$, Gilson Celso A. Chagas JUNIOR ${ }^{1}$, \\ Guilherme OLIVEIRA², Silvia Helena Marques da SILVA³, Santelmo VASCONCELOS², \\ Alessandra Santos LOPES ${ }^{1}$ \\ Universidade Federal do Pará (UFPA), Programa de Pós-graduação em Ciência e Tecnologia de Alimentos (PPGCTA), Laboratório de Processos Biotecnológicos \\ (LABIOTEC), 66075-110, Belém, Pará, Brazil. \\ 2 Instituto Tecnológico Vale (ITV), 66.055-090, Belém, Pará, Brazil \\ 3 Instituto Evandro Chagas (IEC), Laboratório de Micologia, Seção de Bacteriologia e Micologia, Rodovia BR 316, km7, s/n, 67.030-000, Ananindeua, Pará, Brazil \\ * Corresponding author: sfoa@ufpa.br
}

\section{ABSTRACT}

The purpose of this study was to identify the yeasts involved in spontaneous fermentation of cocoa from the Brazilian Amazon region. The fermentation process was carried out experimentally with cocoa seeds from two sites (Medicilândia and Tucumã), State of Pará, northern Brazil, during a six-day period. Totals of 44 yeasts were isolated from Medicilândia and 29 from Tucumã. Molecular identification was carried out by sequencing the D1/D2 region fragment of the rRNA 26S gene, expanded with universal primers for the NL1GC and LS2 eukaryotes. Pichia manshurica and Saccharomyces cerevisiae were identified in Medicilândia and five yeast species (Pichia fermentans, P. kudriavzevii, P. manshurica, S. cerevisiae and Zygosaccharomyces bailii) were identified in Tucumã. The results showed that $P$. manshurica and S. cerevisiae may have potential for use as starter cultures in future studies to improve the quality of cocoa seeds fermented in the Brazilian Amazon region.

KEYWORDS: accession; molecular identification; cocoa beans; Pichia Manshurica; Saccharomyces cerevisiae; Theobroma cacao

\section{Diversidade de leveduras presentes na fermentação de cacau de duas localidades na Amazônia brasileira}

\section{RESUMO}

A proposta deste estudo foi identificar as leveduras envolvidas na fermentação espontânea de cacau da Amazônia brasileira. A fermentação foi realizada em Medicilândia e Tucumá, Pará, Brasil, durante 6 dias. Em total foram obtidos 44 isolados de leveduras de Medicilândia e 29 de Tucumã. A identificação molecular foi realizada por sequenciamento do fragmento da região D1/D2 do gene rRNA 26S, amplificado com primers universais para eucariotos NL1GC e LS2. Em Medicilândia, foram identificadas Pichia manshurica e Saccharomyces cerevisiae. Em Tucumã foram identificadas cinco espécies (Pichia fermentans, P. kudriavzevii, P. manshurica, S. cerevisiae e Zygosaccharomyces bailii). Os resultados sugerem que P. manshurica e $S$. cerevisiae podem ter potencial para uso como culturas starter em estudos futuros, para melhorar a qualidade das sementes de cacau fermentadas na Amazônia brasileira.

PALAVRAS-CHAVE: acesso; identificação molecular; Pichia manshurica; Saccharomyces cerevisiae; Theobroma cacao

\section{INTRODUCTION}

Up to the mid-1990s, Brazilian cocoa was cultivated almost exclusively in the northeastern state of Bahia. However, since the onset of the witch's broom disease, which devastated cocoa plantations in Bahia in the 1980's and early 1990's, the state of Pará, in the Brazilian Amazon region, became an increasingly important source of cocoa (Castelo and Almeida 2015). In 2016, Pará produced 115,127 tons of fermented cocoa seeds (CEPLAC 2016), and to date it is the more important cocoa producer state in Brazil (IBGE 2017).
The fermentation of cocoa seeds is a natural and spontaneous process that is carried out by a succession of microorganisms (Afoakwa et al. 2013; Kadow et al. 2013; Krahmer et al. 2015). Cocoa fermentation is carried out by yeasts and by acetic and lactic acid bacteria. Yeasts play an essential role in fermentation, since these microorganisms are responsible for the production of ethanol from the fermentable sugars present in the pulp of the seeds, also facilitating the intake of oxygen through degradation of the pulp (Ho et al. 2014). Low quantities of oxygen allow for the growth of lactic and acetic acid bacteria, and for the release 
of enzymes that carry out a range of biochemical reactions and which are also producers of higher esters and alcohols, reported as volatile compounds that are essential for the aroma and the flavour of chocolate (Schwan and Wheals 2004; Camu et al. 2008; Owusu et al. 2011). The influence of the region of origin of the cocoa pods, the fermentation methods used in local producer farms, and the role of microorganisms present during fermentation on the quality of the fermented cocoa seeds have been widely investigated in Cuba, Ecuador, Indonesia and Malaysia (Papalexandratou et al. 2011; Papalexandratou et al. 2013; Fernández-Maura et al. 2016). However, there are no reports in the literature about the microflora present during cocoa fermentation in the Amazon region.

The greatest cocoa producer in Pará is the municipality of Medicilândia (Castelo and Almeida 2015; TNC 2015; CEPLAC 2016), including a significant production of organic cocoa in agroforestry systems (Vronski and Olimpio 2016). Most cocoa in Pará is produced in small family farms (TNC 2018) that still use artisanal processing methods. As a consequence of the lack of adequate processing standards, the cocoa from Pará receives low quality classifications, even though the beans have superior intrinsic characteristics of fusion point and fat content (Valente 2012). Considering that the fermentation processes used are rudimentary, with no knowledge of the active microflora (S.F.O. Almeida, personal observation), the objective of this study was to carry out the molecular identification of the diversity of yeasts present during cocoa fermentation in cocoa seeds from Medicilândia and the municpality of Tucumá, an upcoming cacao producer in southeastern Pará (CEPLAC 2016).

\section{MATERIAL AND METHODS}

\section{Fermentation}

Fermentation experiments were carried out in the cities of Medicilândia (03²6'46”S, 52'53'20”W) and Tucumã (06044'51"S, 5109'40"W), Pará State, Brazil. The distance between the two cities is of $963 \mathrm{~km}$. The fermentation processes in each locality were carried out in duplicate in June and July 2014, and all analyses were carried out in the Laboratory for Food Science, Technology and Engineering (LCTEA) of Universidade Federal do Pará - UFPA.

The cocoa pods (belonging to the Forastero group) were manually opened with stainless steel knives 24 hours after harvest, and approximately $70 \mathrm{~kg}$ of seeds were placed in a wooden box with a volume of $0.063 \mathrm{~m}^{3}$ and dimensions of $1.0 \mathrm{~m}$ (length) $\times 0.30 \mathrm{~m}$ (width) $\times 0.25 \mathrm{~m}$ (height). The boxes were covered with banana leaves (approximately 2 $\mathrm{kg}$ ) and burlap bags to maintain the heat produced during fermentation. The fermentation process was monitored for six days. After the first 48 hours of fermentation, the cocoa seeds were turned daily in the boxes to allow for oxygenation and to facilitate adaptation of the acetic bacteria to the medium. Samples of approximately $300 \mathrm{~g}$ (consisting of $20 \mathrm{~g}$ portions) were removed from different points in the fermentation box after $0,24,48,72,96,120$ and 144 hours, placed in sterile polyethylene bags, and frozen immediately after collection.

The temperature was measured during fermentation (at 0 , $24,48,72,96,120$ and 144 hours) by insertion of a skewertype digital thermometer (Incoterm ${ }^{\oplus}$, model 9791.16.1.00, Porto Alegre, RS, Brazil) into the fermenting mass at different points of the fermentation box (surface, middle and bottom). The $\mathrm{pH}$ (970.21, AOAC) was measured according to the Official Methods for Cocoa and its Products (Horwitz 2006).

Isolation, purification and maintenance of isolates

The frozen samples were thawed at room temperature $\left(24^{\circ} \mathrm{C}\right)$, the husks and embryos discarded, and the cotyledons ground using an analytical mill (IKA ${ }^{\oplus}$, mod. A11b). A $25 \mathrm{~g}$ portion of cocoa seeds was asceptically removed from the 300 g sample, transferred to a Stomacher bag and homogenised in $225 \mathrm{~mL}$ of peptone water at $1 \% \mathrm{w} / \mathrm{v}$. Serial decimal dilutions were then prepared up to $10^{-7}$. Aliquots of $1 \mathrm{~mL}$ were plated using the spread plate technique with Petri dishes $(n=3)$ containing potato dextrose agar and the addition of $1 \%$ tartaric acid w/v, and incubated at $30{ }^{\circ} \mathrm{C}$ for one to four days. After the incubation period, the yeast colonies were counted using the standard plate counting method to determine the number of colony forming units per gram of seeds (CFU g ${ }^{-1}$ ) for each point in the fermentation time (Daniel et al. 2009). Colonies showing differing morphological characteristics (shape, size and colour) were submitted to purification, taking at least five colonies from each plate.

The isolates were purified in malt extract agar with the addition of $10 \%$ tartaric acid. The purified yeast colonies were transferred to YEPD agar (15 $\mathrm{gL}^{-1}$ bacteriological agar; $5 \mathrm{gL}^{-1}$ yeast extract; $20 \mathrm{gL}^{-1}$ glucose and $10 \mathrm{gL}^{-1}$ peptone) with the addition of $1 \mathrm{~mL}$ chloramphenicol $/ 100 \mathrm{~mL}$ of medium, and incubated for two days at $30{ }^{\circ} \mathrm{C}$ to obtain pure isolates. After the purification step, the isolates were maintained in YEPD medium at $4{ }^{\circ} \mathrm{C}$ (APHA 2001).

\section{DNA extraction and $P C R$ reaction}

For the extraction and purification of yeast genomic DNA, a portion of each isolated lineage was transferred to a conical flask containing $50 \mathrm{~mL}$ of YEPD broth, and incubated in an orbital shaker (Lucadema ${ }^{\oplus}$, mod. Luca-223, Campinas, SP, Brazil) at $150 \mathrm{rpm}$ and $30^{\circ} \mathrm{C}$ for 12 hours. Aliquots of $1 \mathrm{~mL}$ were transferred to conical tubes, centrifuged at 4,000 rpm for 5 minutes, the supernatant discarded and the DNA extracted and purified using the AxyPrep Multisource Genomic DNA Miniprep kit (Axygen, Biosciences ${ }^{\oplus}$, USA) according to the manufacturer's instructions. The DNA was stored at $-20^{\circ} \mathrm{C}$. A $250 \mathrm{bp}$ fragment of the D1/D2 region of the 26S rRNA gene was amplified with universal primers for gc- NL1 eukaryotes (5'-CGC CCG CCG CGC GCG GCG GGC GGG GCG GGG GCA TAT CAA TAA GCG GAG GAA AAG-3') and 


\section{LS2 (5'-ATT CCC AAA CAA CTC GAC TC-3' Invitrogen $\left.{ }^{\circ}\right)$} (Cocolin-Bisson and Mills 2000).

For the PCR we used a mix consisting of $7.4 \mu \mathrm{L}$ of ultrapure water, $5 \mu \mathrm{L}$ of betaine, $2.5 \mu \mathrm{L}$ of $10 \mathrm{x}$ buffer, $1 \mu \mathrm{L}$ of dNTPs $(10 \mathrm{mM}) ; 2.5 \mu \mathrm{L}$ of each primer, $2 \mathrm{~V}$ of magnesium chloride $-\mathrm{MgCl}_{2}, 0.1 \mu \mathrm{L}$ of Taq DNA polymerase and 2 $\mu \mathrm{L}$ of DNA, giving a total reaction volume of $25 \mu \mathrm{L}$. The PCRs were carried out in an Amplitherm ${ }^{\circ}$ Thermocycler and amplified using the following parameters: initial denaturation at $94^{\circ} \mathrm{C}$ for 3 minutes, 30 cycles at $94^{\circ} \mathrm{C}$ for 35 seconds, 52 ${ }^{\circ} \mathrm{C}$ for 60 seconds and $72{ }^{\circ} \mathrm{C}$ for 75 seconds, followed by a final extension at $72{ }^{\circ} \mathrm{C}$ for 10 minutes.

To verify the amplification and the quantity and integrity of the extracted DNA, the PCR products were subjected to electrophoresis in $2 \%$ agarose gel.

\section{Sample sequencing}

The PCR products were purified sequentially with $65 \%$ isopropanol and $70 \%$ ethanol at $4,000 \mathrm{rpm}$ and $10{ }^{\circ} \mathrm{C}$ for $45 \mathrm{~min}$ and $10 \mathrm{~min}$, respectively. The cycle sequencing reactions were then carried out with $\sim 20$ ng of amplified DNA using the Big Dye Terminator kit v. 3.1 (ThermoFisher ${ }^{\circ}$ ), as recommended by the manufacturer. The bi-directional reactions were sequenced and analysed in a DNA Analyzer ABI 3730 (ThermoFisher ${ }^{\bullet}$, Carlsbad, CA, USA). Sequence assembly with MAFFT v. 7.2 (Katoh and Standley 2013) was based on maximum likelihood carried out using the software Geneious R10 (Biomatters), and the similarity analysis by BLAST searches in the GenBank (http:/blast.ncbi.nlm.nih. gov/Blast.cgi) (Guindon and Gascuel 2003).

\section{RESULTS}

\section{Fermentation parameters}

As expected, the $\mathrm{pH}$ and temperature profiles of the cocoa seeds varied during the fermentation process (Figure 1). The initial $\mathrm{pH}$ values were 5.33 and 5.25 for the cocoa seeds from Medicilândia and Tucumã, respectively. In both cases the $\mathrm{pH}$ decreased up to 48 hours, followed by an increase up to the end of the fermentation. The $\mathrm{pH}$ values at the end of fermentation were 5.0 and 6.48 in Medicilândia and Tucumã, respectively.

The average temperature profiles for the cocoa seeds from both locations showed a significant increase after the first 48 hours of fermentation, with temperatures above $40^{\circ} \mathrm{C}$, mainly due to the acetic bacteria metabolism, which is an exothermic process (Ho et al. 2014). In Medicilândia, the highest mean temperature was recorded after 144 hours, when it reached $47^{\circ} \mathrm{C}$ (Figure 1B), whereas in Tucumã, the highest mean temperature of $45.5^{\circ} \mathrm{C}$ was reached after 120 hours.

\section{Yeast diversity}

Overall 73 yeast isolates were obtained from the two localities (44 in Medicilândia and 29 in Tucumã). The colonies showed morphological differences in colour (white and yellowishwhite), general appearance (smooth and rough surfaces) and gloss (bright and opaque). Under the microscope, the yeast cells presented round and oval shapes. After 48 and 120 hours of fermentation only a small number of isolates were obtained at the two localities, which can be attributed to changes and adaptations in the microbial groups.

Yeast count at 0 and 144 hours of fermentation was $10^{6}$ CFU. $\mathrm{g}^{-1}$ in Medicilândia, while in Tucumã the initial yeast count was $10^{8} \mathrm{CFUg}^{-1}$ and reached between $10^{5}$ and $10^{7} \mathrm{CFUg}^{-1}$ at the end of the fermentation process (Table 1 ), confirming the presence of yeasts throughout the entire fermentation process, and not just in the first few hours. Pichia and Saccharomyces yeasts were predominant at both localities (Table 2). In Medicilândia, two species were identified, Saccharomyces cerevisiae (63.4\%) and Pichia manshurica (36.6\%). During the first 24 hours of fermentation, $S$. cerevisiae was dominant among 21 identified isolates. After 96 hours, however, $P$. manshurica showed to be more adapted
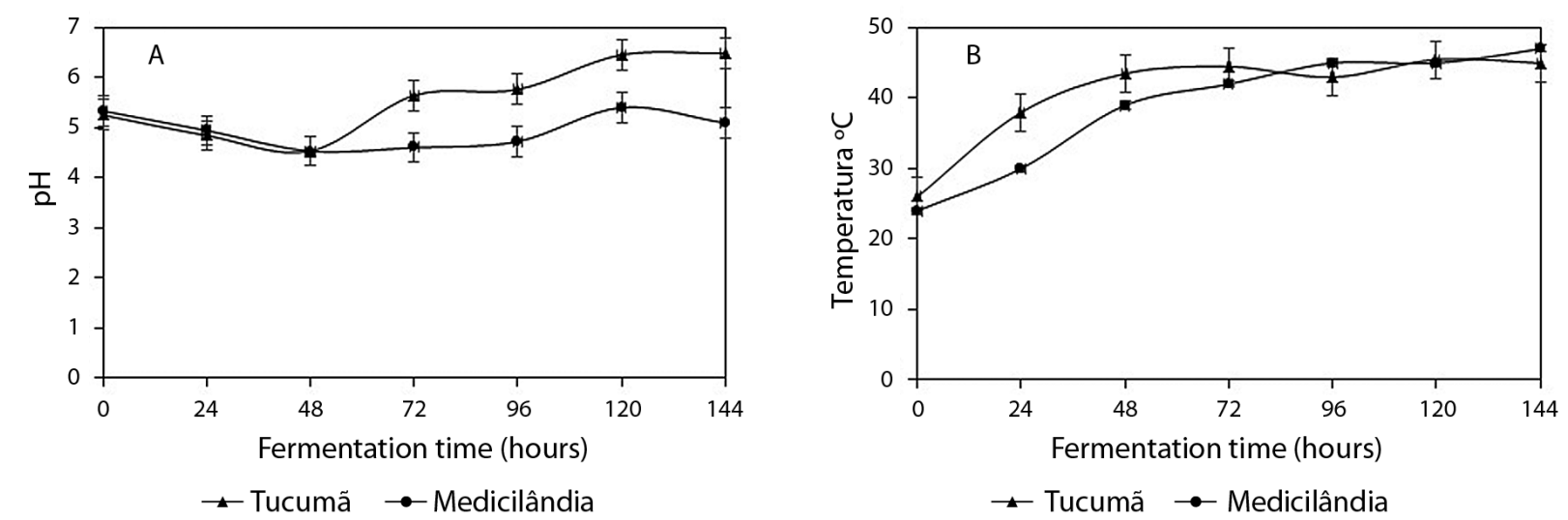

Figure 1. Average $\mathrm{pH}(\mathrm{A})$ and temperature (B) values during the fermentation process of cocoa seeds in the localities of Medicilândia and Tucumã (Pará state, Brazilian Amazon region). 
Table 1. Average total yeast count (CFU/g cocoa seeds) during cocoa fermentation in two localities in Pará state, Brazilian Amazon region.

\begin{tabular}{lcccccccc}
\hline \multicolumn{7}{c}{ Fermentation time (hours) } \\
\hline Locality & 0 & 24 & 48 & 72 & 96 & 120 & 144 & 168 \\
Tucumã & $1.6 \times 10^{8}$ & $1 \times 10^{7}$ & $5 \times 10^{6}$ & $5 \times 10^{5}$ & $5.1 \times 10^{5}$ & $1.3 \times 10^{7}$ & $1.5 \times 10^{7}$ & $1 \times 10^{7}$ \\
Medicilândia & $1.8 \times 10^{6}$ & $5.7 \times 10^{5}$ & $6 \times 10^{3}$ & $1 \times 10^{5}$ & $1.3 \times 10^{5}$ & $1 \times 10^{6}$ & $3 \times 10^{6}$ & $1 \times 10^{6}$ \\
\hline
\end{tabular}

Table 2. Distribution of the dominant yeast species isolated during the fermentation of cocoa seeds in Medicilândia and Tucumã, state of Pará, in the Brazilian Amazon region. The number of isolates per yeast species is shown for samples taken at different fermentation times at each locality. Accession numbers of reference sequences in GenBank are indicated. \% identity = identity coincidence between two sequences estimated by BLAST; E value = probability of a random correspondence with a GenBank sequence.

\begin{tabular}{|c|c|c|c|c|c|c|c|c|c|c|}
\hline \multirow{2}{*}{ Yeast species } & \multirow{2}{*}{ Accession number } & \multirow{2}{*}{$\%$ identity } & \multirow{2}{*}{$E$ value } & \multicolumn{7}{|c|}{ Fermentation time (hours) } \\
\hline & & & & 0 & 24 & 48 & 72 & 96 & 120 & 144 \\
\hline \multicolumn{11}{|c|}{ Medicilândia } \\
\hline Pichia manshurica & KU316788.1 & 100 & $6 e-119$ & 1 & 2 & - & - & 3 & 5 & 4 \\
\hline Saccharomyces cerevisiae & EU441887.1 & 99 & $8 e-132$ & 4 & 17 & - & - & 1 & 2 & 2 \\
\hline \multicolumn{11}{|c|}{ Tucumã } \\
\hline Pichia fermentans & KU820954.1 & 100 & $8 e-117$ & 1 & - & - & - & 1 & - & - \\
\hline Pichia kudriavzevii & KU316741.1 & 100 & $5 e-92$ & - & - & - & 1 & - & - & - \\
\hline Pichia manshurica & KU316788.1 & 100 & $5 e-119$ & - & 1 & - & - & 3 & 1 & 1 \\
\hline Saccharomyces cerevisiae & EU441887.1 & 99 & $8 e-132$ & 1 & 2 & - & - & 1 & - & - \\
\hline Zygosaccharomyces bailii & KJ433981.1 & 100 & $2 e-123$ & - & 2 & - & - & - & - & - \\
\hline
\end{tabular}

to the environment, and was the dominant species among a total of 12 isolates. In Tucumã, the diversity of yeasts was greater than in Medicilândia, with five identified species (Pichia fermentans, P. kudriavzevii, P. manshurica, S. cerevisiae and Zygosaccharomyces bailii). Pichia manshurica showed the highest number of isolates (3) throughout the fermentation process. Two Zygosaccharomyces bailii isolates were obtained from the 24 hour sample, and contamination by filamentous fungi was observed after 96 hours of fermentation. The role played by filamentous fungi in the microbial succession during the fermentation of cocoa seeds is not well known.

The GenBank accession numbers of the nucleotide sequences determined in this study are MF043900 to MF043908 and MF043882 to MF043899.

\section{DISCUSSION}

The decrease in $\mathrm{pH}$ within the first 48 hours of fermentation was the result of the permeation of organic acids from the seed core. The sugars present in the pulp (specially glucose, sucrose and fructose) are primary substrates for yeasts and lactic acid bacteria. The ethanol produced by the yeasts serves as a substrate for acetic acid bacteria, which metabolize the ethanol produced by the yeasts (Galvéz et al. 2007). The increase in $\mathrm{pH}$ after 48 hours of fermentation was due to the consumption of the citric acid present in the pulp by the yeasts (Galvéz et al. 2007; Lefeber et al. 2011; Moreira et al. 2013). The more neutral $\mathrm{pH}$ values found in the present study were similar to those reported in studies on cocoa fermentation carried out in the Ivory Coast and Cuba (Samagaci et al. 2014;
Fernández-Maura et al. 2016). Cocoa seeds with a final $\mathrm{pH}$ below 4.5 show the potential to yield the characteristic flavour of chocolate, while this potential is significantly increased when the $\mathrm{pH}$ ranges from 5.0 to 5.5 (Amin et al. 2002). The $\mathrm{pH}$ values found in the cocoa seeds from both locations can be considered as low acidic seeds, and they produce a 'milder' chocolate with international notoriety in the manufacture of high quality products (Amin et al. 2002).

The temperature progression in our study was considered satisfactory for a successful fermentation process (Camu et al. 2007,2008 ), and was similar to that reported in other studies (Papalexandratou et al. 2011; Moreira et al. 2013), who found a mean maximum temperature of $46.8^{\circ} \mathrm{C}$ after 144 hours of fermentation as a result of microbial metabolic activity.

The presence and growth of yeasts during fermentation can be affected by many factors, such as the initial microflora, the use of starter cultures, the chemical composition of the cocoa seeds, the fermentation temperature and the interactions between different microorganisms (Gomes 2007). AranaSánchez et al. (2015) and Menezes et al. (2016) reported microbial counts of around $10^{8}$ and $10^{9}$ for Saccharomyces during the fermentation of cocoa in Mexico and Brazil, which is similar to those found in the present work. In a study carried out in Australia, values of $10^{6}$ and $10^{7} \mathrm{CFUg}^{-1}$ were reported after 72 hours of cocoa fermentation (Ho et al. 2014), suggesting that cocoa fermentation in other climate zones can affect microbial growth. Pichia manshurica is able to metabolize some acids, including lactic acid (Franco and Pérez-Díaz 2012), which could explain the predominance of this species in the last days of the cocoa fermentation process. 
Saccharomyces cerevisiae is the most commonly reported yeast during alcoholic fermentation in several fermentation processes, due to its ability to produce and tolerate high concentrations of ethanol and sugars in an acid medium (Zinnai et al. 2013). In Brazil and in other countries (Ghana, Mexico, Malaysia), S. cerevisiae is the dominant species in the fermentation of cocoa, due to its ability to adapt to changes in $\mathrm{pH}$ and temperature, and also due to its low nutritional needs (Papalexandratou et al. 2011; Pereira et al. 2012; Moreira et al. 2013; Papalexandratou et al. 2013; Arana-Sánchez et al. 2015; Batista et al. 2015). Pichia manshurica, on the other hand, was only known from cocoa fermentation in one study carried out in Cuba (Fernández-Maura et al. 2016). Our results suggest that both Saccharomyces cerevisiae and Pichia manshurica are important yeasts in cocoa fermentation in the Amazon region, and their presence throughout the fermentation processes highlights the resistance of these yeasts to the environmental conditions during fermentation. Zygosaccharomyces bailii strains, which were isolated only from the initial 24 hours of fermentation in Tucumá, has been reported to produce unwanted changes in food, specially in wine fermentation, due to excessive production of carbon dioxide $\left(\mathrm{CO}_{2}\right)$ and alteration of sensory characteristics (Zuehlke et al. 2013).

\section{CONCLUSIONS}

We identified five yeast species during the spontaneous fermentation process of cocoa seeds in two localities in Pará state, in the Brazilian Amazon. The detection of Pichia manshurica is unprecedented in cocoa fermentations in this region. Saccharomyces cerevisiae and P.manshurica should be further examined for their role in the quality of cocoa from the Brazilian Amazon and their potential for the development of starter cultures.

\section{ACKNOWLEDGMENTS}

This study was financed by the Instituto Tecnológico Vale (ITV) (CacauP2). The authors are grateful to the Graduate Program in Food Science and Technology of Universidade Federal do Pará (PPGCTA/UFPA) for the infrastructure offered. GO is a research fellow of Conselho Nacional de Desenvolvimento Científico e Tecnológico - CNPq (proc. \# 309312/2012-4).

\section{REFERENCES}

Afoakwa, E.O.; Kongor, J.E.; Takrama, J.; Budu, A.S. 2013. Changes in nib acidification and biochemical composition during fermentation of pulp pre-conditioned cocoa (Theobroma cacao L) seeds. International Journal of Food Microbiology, 20: 1843-1853.

Amin, I.; Jinap, S.; Jamilah, B.; Harikrisna, K.; Biehl, B. 2002. Analysis of vicilin (7S)-class globulin in cocoa cotyledons from various genetic origins. Journal of the Science of Food and Agriculture, 82: 728-732.
APHA. 2001. American Public Health Association. Compendiun of Methods for the Microbiological Examination of Foods. 3th ed. APHA, Washington, 624p.

Arana-Sánchez, A.; Segura-García, L.E.; Kirchmayer, M.; OrozcoÁvila, I.; Lugo-Cervantes, E.; Gschaedler-Mathis, A. 2015. Identification of predominant yeasts associated with artisan Mexican cocoa fermentations using culture-dependent and culture-independent approaches. World Journal of Microbiology and Biotechnology, 31: 359-69.

Batista, N.N.; Ramos, C.L.; Dias, D.R.; Pinheiro, A.C.M.; Schwan, R.F. 2015. Dynamic behavior of Saccharomyces cerevisiae, Pichia kluyveri and Hanseniaspora uvarum during spontaneous and inoculated cocoa fermentations and their effect on sensory characteristics of chocolate. Food Science and Technology, 63: 221-227.

Branco, P.; Francisco, D.; Chambon, C.; Hébraud, M.; Arneborg, N.; Almeida, M.G. 2014. Identification of novel GAPDH-derived antimicrobial peptides secreted by Saccharomyces cerevisiae and involved in wine microbial interactions. Applied Microbiology and Biotechnology, 98: 843-853.

Camu, N.; De Winter, T.; Verbrugghe, K.; Cleenwerck, I.; Vandamme, P.; Takrama, J. S.; Vancanneyt, M.; De Vuyst, L. 2007. Dynamics and biodiversity of populations of lactic acid bacteria and acetic acid bacteria involved in spontaneous heap fermentation of cocoa seeds in Ghana. Applied of Environmental Microbiology, 73: 1809-1824.

Camu, N.; Gonzalez, A.; De Winter, T.; Van Schoor, A.; De Bruyne, K.; Vandamme, P.; Takrama, J.S.; Addo, S.K.; De Vuyst, L. 2008. Influence of turning and environmental contamination on the dynamics of populations of lactic acid and acetic acid bacteria involved in spontaneous cocoa bean heap fermentation in Ghana. Applied of Environmental Microbiology, 74: 86-98.

Castelo, T.B.; Almeida, O.T. 2015. Desmatamento e uso da terra no Pará. Política Agrícola, XXIV: 98-111.

CEPLAC. 2016. Ministério de Agricultura, Pecuária e Abastecimento - MAPA, Comissão Executiva da Lavoura Cacaueira - CEPLAC. Mapa da distribuição da produção de cacau em amêndoas segundo os municípios acompanhados pela CEPLAC/SUEPA - julho 2016. Map of cocoa production distribution in Pará state in 2016. (http://www.ceplacpa.gov.br/site/wp-content/ uploads/2016/09/SAFRA-2016-JULHO-RELATORIO.pdf ). Accessed on 07 Mar 2018.

Cocolin, L.; Bisson, L. 2000. Direct profiling of the yeast dynamics in wine fermentations. FEMS Microbiology Letters, 189: 81-87.

Crafack, M.; Mikkelsen, M.B.; Saerens, S.; Knudsen, M.; Blennow, A.; Lowor, S.; et al 2013. Influencing cocoa flavour using Pichia kluyveri and Kluyveromyces marxianus in a defined mixed starter culture for cocoa fermentation. International Journal of Food Microbiology, 167: 103-116.

Crafack, M.; Keul, H.; Eskildsen, C.E.; Petersen, M.A.; Saerens, S; Blennow, A.; Nielsen, D.S. 2014. Impact of starter cultures and fermentation techniques on the volatile aroma and sensory profile of chocolate. Food Research International, 63: 306-316.

Daniel, H.M.; Vrancken, G.; Takrama, J.F.; Camu, N.; De Vos, P.; De Vuyst, L. 2009. Yeast diversity of Ghanaian cocoa bean heap fermentations. FEMS Yeast Research, 9: 774-783. 
Fernández Maura. Y.; Balzarini, T.; Clapé, B.P.; Evrard, P.; De Vuyst, L.; Daniel, H. M. 2016. The environmental and intrinsic yeast diversity of Cuban cocoa bean heap fermentations. International Journal of Food Microbiology, 233: 34-43.

Franco, W.; Pérez-Díaz, I.M. 2012. Role of selected oxidative yeasts and bacteria in cucumber secondary fermentation associated with spoilage of the fermented fruit. Food Microbiology, 32: 338-344.

Gomes, F.C.O.; Silva, C.L.; Marini, M.M.; Oliveira, E.S.; Rosa, C.A. 2007. Use of selected indigenous Saccharomyces cerevisiae strains for the production of the traditional cachaça in Brazil. Journal of Applied Microbiology, 103: 2438-2447.

Guindon, S.; Gascuel, O. 2003. A simple, fast, and accurate algorithm to estimate large phylogenies by maximum likelihood. Systematic Biology, 52: 696-704.

Ho, V.T.T.; Zhao, J.; Fleet, G. 2014. Yeasts are essential for cocoa bean fermentation. International Journal of Food Microbiology, 174: 72-87.

Horwitz, W. 2006. Official methods of analysis of the AOAC International. 16th ed. AOAC, Arlington, (http://www.aoac. org/aoac_prod_imis/AOAC/Publications/Official_Methods_ of_Analysis/AOAC_Member/Pubs/OMA/AOAC_Official_ Methods_of_Analysis.aspx) Accessed on 02 Mar 2016.

IBGE. 2017. Instituto Brasileiro de Geografia e Estatística. Levantamento Sistemático da Produção Agrícola - LSPA (Janeiro 2017). IBGE, Braília, 108p. (ftp://ftp.ibge.gov.br/ Producao_Agricola/Levantamento_Sistematico_da_Producao_ Agricola_[mensal]/Fasciculo/2017/lspa_201712.pdf). Accessed on 30 Sep 2018.

Kadow, D.; Bohlmann, J.; Phillips, W.; Lieberei, R. 2013. Identification of main fine or flavor components in two genotypes of the cocoa tree (Theobroma cacao L.). Journal of Applied Botany and Food Quality, 8: 90-98.

Krähmer, A.; Engel, A.; Kadow, D.; Ali, N.; Umaharan, P.; Kroh, L.W.; Schulz, H. 2015. Fast and neat - Determination of biochemical quality parameters in cocoa using near infrared spectroscopy. Food Chemistry, 181: 152-159.

Lagunes Gálvez, S.; Loiseau, G.; Paredes, J.L.; Barel, M.; Guiraud, J.P. 2007. Study on the microflora and biochemistry of cocoa fermentation in the Dominican Republic. International Journal of Food Microbiology, 114: 124-130.

Leal, G.A.; Gomes, L.H.; Efraim, P.; De Almeida, T.; Flavio, C.; Figueira, A. 2008. Fermentation of cacao (Theobroma cacao L.) seeds with a hybrid Kluyveromyces marxianus strain improved product quality attributes. FEMS Yeast Research, 8: 788-798.

Lefeber, T.; Gobert, W.; Vrancken, G.; Camu, N.; De Vuyst, L. 2011. Dynamics and species diversity of communities of lactic acid bacteria and acetic acid bacteria during spontaneous cocoa bean fermentation in vessels. Food Microbiology, 28: 457-464.

Lefeber, T.; Papalexandratou, Z.; Gobert, W.; Camu, N.; De Vuyst, L. 2012. On-farm implementation of a starter culture for improved cocoa bean fermentation and its influence on the flavour of chocolates produced thereof. Food Microbiology, 30: 379 - 392.

Menezes, A.G.T.; Batista, N.N.; Ramos, C.L.; Silva, A.R.A.; Efraim, P.; Pinheiro, A.C.M.; Schwan, R.F. 2016. Investigation of chocolate produced from four different Brazilian varieties of cocoa (Theobroma cacao L.) inoculated with Saccharomyces cerevisiae. Food Research International, 81: 83-90.

Moreira, I.M.V.; Pedrozo, M.G.C.; Duarte, M.W.F.; Dias, D.R.; Schwan, R.F. 2013. Microbial succession and the dynamics of metabolites and sugars during the fermentation of three different cocoa (Theobroma cacao L.) hybrids. Food Research International, 54: 9-17.

Owusu, M.; Petersen, M.A.; Heimdal, H. 2012. Effect of fermentation method, roasting and conching conditions on the aroma volatiles of dark chocolate. Journal of Food Processing Preservation, 36: 446-456.

Papalexandratou, Z.; Falony, G.; Romanens, E.; Jimenez, J.C.; Amores, F.; Daniel, H. M.; De Vuyst, L. 2011. Species Diversity, Community Dynamics, and Metabolite Kinetics of the Microbiota Associated with Traditional Ecuadorian Spontaneous Cocoa Bean Fermentations. Applied and Environmental Microbiology, 77: 7698-7714.

Papalexandratou, Z.; Lefeber, T.; Bahrim, B.; Lee, O.S.; Daniel, H.M.; Vuyst, L.D. 2013. Hanseniaspora opuntiae, Saccharomyces cerevisiae, Lactobacillus fermentum, and Acetobacter pasteurianus predominate during well-performed Malaysian cocoa bean box fermentations, underlining the importance of these microbial species for a successful cocoa bean fermentation process. Food Microbiology, 35: 73-85.

Pereira, G.V.M.; Miguel, M.G.C.P.; Ramos, C.L.; Schwan, R.F. 2012. Microbiological and physicochemical characterization of small-scale cocoa fermentations and screening of yeast and bacteria strains to develop a defined starter culture. Applied and Environmental Microbiology, 78: 5395-5405.

Ramos, C.L.; Dias, D.R.; Miguel, M.G.C.P.; Schwan, R.F. 2014. Impact of different cocoa hybrids (Theobroma cacao L.) and $S$. cerevisiae UFLA CA11 inoculation on microbial communities and volatile compounds of cocoa fermentation. Food Research International, 64: 908-918.

Reis, R.V.; Bassi, A.P.G.; Silva, J.C.G.; Ceccato-Antonini, S.R. 2013. Characteristics of Saccharomyces cerevisiae yeasts exhibiting rough colonies and pseudohyphal morphology with respect to alcoholic fermentation. Brazilian Journal of Microbiology, 44: 1121-1131.

Schwan, R.F.; Wheals, A.E. 2004. The microbiology of cocoa fermentation ans its role in chocolate quality. Critical Reviews in Food Science and Nutrition, 44: 205-221.

Saltini, R.; Akkerman, R.; Frosch, S. 2013. Optimizing chocolate production through traceability: a review of the influence of farming practices on cocoa bean quality. Food Control, 29: 167-187.

Samagaci, L.; Ouattara, H.G.; Goualié, B.G.; Niamke, S.L. 2014. Growth capacity of yeasts potential starter strains under cocoa fermentation stress conditions in Ivory Coast. Emirates Journal of Food and Agriculture, 26: 861-870.

Santos, A.; Marquina, D.; Leal, J.A.; Peinado, J.M. 2000. (1/6)-b-DGlucan as cell wall receptor for Pichia membranifaciens killer toxin. Applied and Environmental Microbiology, 66: 1809-1813.

TNC. 2015. Caminhos do desenvolvimento verde na agenda do Pará 2030: Desenvolvimento de cenários de uso da terra e custos de implantação. The Nature Conservacy Brasil, Belém, 141p. 
(https://www.nature.org/media/brasil/caminhos-des-verdepara-2030.pdf). Accessed on 30 Sep 2018.

Valente, A.M. 2012. Estudo da potencialidade de registro de indicação geográfica a produção de cacau no município de Medicilândia/PA. Master's thesis. Universidade Federal do Pará - UFPA, Brazil. 120p. (http://repositorio.ufpa.br/jspui/ handle/2011/9897). Accessed on 30 Sep 2018.

Vronski, M.; Olimpio, S.M. 2016. Production of the organic cocoa in the Amazon: a case study of the Amazon Organic Products Cooperative - COPOAM. REBRAE, 9: 351-361.
Zinnai, A.; Venturi, F.; Sanmartin, C.; Andrich, G. 2013. The kinetics of alcoholic fermentation by two yeast strains in high sugar concentration media. Journal of Bioprocessing and Biotechniques, 3: $1-5$.

Zuehlke, J.M.; Petrova, B.; Edwards, C.G. 2013. Advances in the control of wine spoilage by Zygosaccharomyces and Dekkera/Brettanomyces. Annual Review of Food Science and Technology, 4: 57-78.

RECEIVED: $18 / 10 / 2017$

ACCEPTED: 14/09/2018

ASSOCIATE EDITOR: João Paulo Silva 